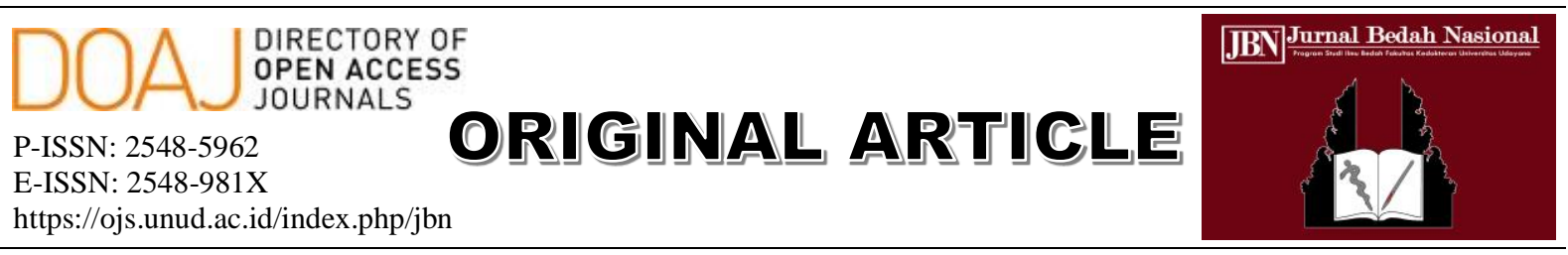

\title{
Simvastatin Memperbaiki Degerasi Hidropis dan Nekrosis Sel Hepatosit Mencit Subtotal Nefrektomi
}

\author{
I Dewa Gede Amara Putra Wibawa ${ }^{1}$, Komang Trisna Sumadewi², Putu Nita Cahyawati ${ }^{3^{*}}$ \\ ${ }^{1}$ Mahasiswa Fakultas Kedokteran dan Ilmu Kesehatan Universitas Warmadewa. \\ ${ }^{2}$ Bagian Anatomi dan Histologi, Fakultas Kedokteran dan Ilmu Kesehatan Universitas Warmadewa. \\ ${ }^{3}$ Bagian Farmakologi dan Farmasi, Fakultas Kedokteran dan Ilmu Kesehatan Universitas Warmadewa.
}

*Penulis korespondensi: putunitacahyawati@gmail.com.

\begin{abstract}
ABSTRAK
Latar belakang: Gagal ginjal kronik (GGK) merupakan salah satu penyakit dengan tingkat mortalitas yang tinggi. Pada pasien GGK, golongan obat statin digunakan untuk mengatasi kondisi dislipidemia dan mencegah kelainan kardiovaskular. Selama ini banyak penelitian lebih terfokus meneliti efek pemberian statin terhadap kondisi ginjal dibandingkan dengan kondisi hepar. Penelitian ini bertujuan untuk mengetahui efek simvastatin terhadap perubahan pada degenerasi hidropis dan nekrosis sel hepatosit mencit model subtotal nefrektomi. Metode: Lima belas ekor mencit (Mus musculus L.) jantan, galur Swiss, umur 3 bulan, berat badan 30-40 gram digunakan pada penelitian ini. Mencit dibagi menjadi 3 kelompok perlakuan secara random yaitu kelompok subtotal nefrektomi ( $\mathrm{SN}, \mathrm{n}=5)$, kelompok simvastatin dosis 5,2 mg/kgBB (S5, $\mathrm{n}=5$ ), dan kelompok simvastatin dosis 10,4 mg/kgBB (S10, n=5). Hasil: Hasil pemeriksaan histopatologi menunjukkan bahwa rerata degenerasi hidropis pada kelompok SN $(1,24 \pm 0,19)$, kelompok S5 $(0,64 \pm 0,11)$, dan kelompok S10 $(0,92 \pm 0,41)$. Terdapat perbedaan signifikan pada penilaian degenersi hidropis pada kelompok SN dan kelompok S5 $(p<0,05)$. Rerata degenerasi hidropis pada kelompok SN $(1,24 \pm 0,19)$, kelompok S5 $(0,64 \pm 0,11)$, dan kelompok S10 $(0,92 \pm 0,41)$. Terdapat perbedaan signifikan antara kelompok hewan yang memperoleh simvastatin (S5 dan S10) dengan kelompok SN ( $<0,05)$. Simpulan: Simvastatin memperbaiki degerasi hidropis dan nekrosis sel hepatosit mencit subtotal nefrektomi.
\end{abstract}

Kata kunci: simvastatin, degenerasi hidropis, nekrosis, hepar, subtotal nefrektomi.

DOI: https://doi.org/10.24843/JBN.2022.v06.i01.p04

\begin{abstract}
Background: Background: Chronic kidney disease (CKD) is a disease with a high mortality rate. In patients with CKD, statin was used to treat dyslipidemia and to prevent cardiovascular disease. All this time, many studies more focus on examining the effect of statins on kidney conditions compared to hepatic conditions. This study aims to determine the effect of simvastatin on hydropic degeneration and necrosis of hepatocyte cells in mice with subtotal nephrectomy. Case: Fifteen male mice (Mus musculus L.), Swiss strain, 3 months old, 30-40 gram body weight were used in this study. Mice were divided into 3 treatment groups randomly, namely the subtotal nephrectomy group $(\mathrm{SN}, \mathrm{n}=5)$, the simvastatin group with a dose of $5.2 \mathrm{mg} / \mathrm{kg} \mathrm{BW}(\mathrm{S} 5, \mathrm{n}=5)$, and the simvastatin group with a dose of $10.4 \mathrm{mg} / \mathrm{kg}$ BW (S10, n=5). The results of the histopathological examination showed that the mean of hydropic degeneration was in the $\mathrm{SN}$ group $(1.24 \pm 0.19)$, the $\mathrm{S} 5$ group $(0.64 \pm 0.11)$, and the $\mathrm{S} 10$ group $(0.92 \pm 0.41)$. There was a significant difference in the assessment of hydropic degeneration in the SN group and the $\mathrm{S} 5$ group $(\mathrm{p}<0.05)$. The mean of hydropic degeneration was in the $\mathrm{SN}$ group $(1.24 \pm 0.19)$, the S5 group (0.64 \pm 0.11$)$, and the $S 10$ group $(0.92 \pm 0.41)$. There was a significant difference between the simvastatin groups (S5 and S10) and the SN group ( $\mathrm{p}<0.05)$. Conclusion: Simvastatin improves hydropic degeneration and necrosis of hepatocyte cells in mice subtotal nephrectomy.
\end{abstract}

Keywords: simvastatin, hydropic degeneration, necrosis, liver, subtotal nephrectomy. 


\section{PENDAHULUAN}

Gagal ginjal kronik (GGK) merupakan salah satu penyakit dengan tingkat mortalitas yang tinggi. Secara global, prevalensinya mencapai 9,1\% dan sebanyak 1-2 juta orang di dunia dilaporkan meninggal karena GGK. Angka kematian dilapokan meningkat sebesar 41,4\% pada tahun $2017 .{ }^{1}$

Selama ini banyak penelitian lebih terfokus meneliti efek pemberian statin terhadap kondisi ginjal pada GGK dibandingkan dengan kondisi hepar. Kondisi ginjal dan hepar sesungguhnya sangat berkaitan terutama dalam fungsi metabolisme, ekskresi, maupun sekresi. ${ }^{2}$ Hepar merupakan kelenjar terbesar yang ada di dalam tubuh. Hepar berperan penting dalam proses metabolisme karbohidrat, lemak, protein, metabolisme obat dan menggontrol kadar gula darah. ${ }^{3}$ Sebuah studi melaporkan bahwa terdapat hubungan antara kerusakan hepar, penurunan fungsi filtrasi glomerulus, dan derajat albuminuria. ${ }^{4}$

Pada gagal ginjal kronik kadar blood urea nitrogen (BUN) dan kreatinin serum akan meningkat. Urea sebagai zat toksik yang ada di dalam tubuh akan didetoksifikasi oleh hepar dan dikeluarkan melalui urin. ${ }^{5,6}$ Jejas yang terjadi pada sel hepar dapat bersifat reversibel maupun irreversibel. Jejas reversibel pada sel hepar berupa pembengkakan sel dan degenerasi lemak, sedangkan jejas irreversibel berupa nekrosis dan fibrosis. Gambaran mikroskopik dari nekrosis dapat berupa terjadinya piknosis, karioreksis, dan kariolisis. $^{7}$

Kerusakan pada hepar salah satunya dapat dipicu oleh konsumsi obat. Konsumsi obat dalam jangka waktu tertentu dan jenis obat dapat bersifat toksik pada hepar. Salah satu obat yang dilaporkan dapat merusak hepar adalah statin. ${ }^{8}$ Berdasarkan hasil penelitian sebelumnya, penggunaan atorvastatin dan simvastatin dilaporkan dapat menyebabkan cedera hepar. ${ }^{9}$ Para ahli belum mengetahui bagaimana mekanisme statin dapat merusak jaringan di hepar tersebut. ${ }^{10}$ Kejadian liver injury akibat penggunaan statin yang kemungkinan akibat efek jangka panjang. ${ }^{11}$ Atorvastatin, simvastatin, dan lovastatin dapat bersifat toksik terhadap hepatosit melalui pembentukan oxidative-stress, sehingga menghambat respirasi mitokondria yang menyebabkan kematian sel hepatosit. ${ }^{12,13}$ Namun, dalam beberapa tahun terakhir statin menarik lebih banyak perhatian karena memiliki efek lain yaitu: efek antioksidan, antiinflamasi, dan antiiskemik. ${ }^{14-16}$ Efek antioksidan statin kemungkinan terjadi melalui mekanisme lipid-lowering-dependent dan lipid-lowering-independent. ${ }^{17}$

Statin adalah kelompok obat $H M G-C o A$ reductase inhibitor yang mencegah produksi kolesterol endogen, dengan menghambat jalur pembentukan L-mevalonate. Pada pasien GGK, golongan obat statin digunakan untuk mengatasi kondisi dislipidemia sehingga mengurangi risiko terjadinya kelainan kardiovaskular dan pencegahan kerusakan ginjal lebih lanjut. ${ }^{18,19}$ Pada penelitian terdahulu, pemberian simvastatin pada model hewan coba GGK, dilaporkan mampu memperbaiki fungsi ginjal melalui perbaikan kadar serum kreatinin, proteinuria, serta perbaikan pada morfologi glomerulus dan tubulus. ${ }^{20,21}$

Berdasarkan data-data penelitian sebelumnya, diketahui bahwa penelitian tentang efek statin pada sel hepar pada kondisi gagal ginjal kronik masih terbatas dan kontroversi. Oleh karenanya, peneliti tertarik untuk mengetahui bagaimana gambaran perubahan struktur hepar pada kondisi gagal ginjal kronik yang memperoleh terapi statin dengan menggunakan model hewan coba gagal ginjal kronik. 


\section{METODE}

\section{Kelaikan etik}

Penelitian ini telah mendapatkan izin dari Komisi Etik Penelitian Fakultas Kedokteran Universitas Udayana / Rumah Sakit Umum Pusat Sanglah Denpasar berdasarkan surat keterangan kelaikan etik dengan nomor 2243/UN14.2.2.VII.14/LP/2018.

\section{Hewan coba}

Penelitian ini menggunakan lima belas ekor mencit (Mus musculus L.) jantan, galur Swiss, umur 3 bulan, berat badan 30-40gram dan tampak sehat. Hewan diperoleh dari Unit Pengembangan Hewan Penelitian, Fakultas Kedokteran Universitas Udayana, Denpasar, Bali. Mencit dibagi menjadi 3 kelompok perlakuan secara random yaitu kelompok subtotal nefrektomi ( $\mathrm{SN}, \mathrm{n}=5)$, kelompok simvastatin dosis $5,2 \mathrm{mg} / \mathrm{kgBB}(\mathrm{S} 5, \mathrm{n}=5)$, dan kelompok simvastatin dosis $10,4 \mathrm{mg} / \mathrm{kgBB}$ $(\mathrm{S} 10, \mathrm{n}=5)$. Hewan coba dipelihara pada kondisi laboratorium standar yaitu; temperatur $23 \pm 2^{\circ} \mathrm{C}$, kelembaban $50 \pm 5 \%$, siklus teranggelap 12 jam. Hewan mendapatkan akses ad libitum terhadap air minum (tap water) dan makanan. ${ }^{20}$

\section{Prosedur penelitian}

Penelitian diawali dengan periode aklimatisasi selam 7 hari. Selanjutnya dilakukan prosedur operasi sesuai dengan kelompok hewan tersebut. Pada kelompok SN dilakukan prosedur operasi subtotal nefrektomi. Prosedur operasi subtotal nefrektomi dilakukan dengan melakukan insisi pada regio flank kedua ginjal, dengan terlebih dahulu menghilangkan ginjal kanan, kemudian pada hari berikutnya dilanjutkan dengan menghilangkan polus superior dan inferior ginjal kiri. ${ }^{20,22}$ Pada kelompok S5 dan S10 dilakukan prosedur operasi nefrektomi 5/6 subtotal kemudian diberikan simvastatin dengan dosis $5,2 \mathrm{mg} / \mathrm{kgBB}$ dan $\quad 10,4$ $\mathrm{mg} / \mathrm{kgBB}$. Pada penelitian ini, digunakan obat simvastatin (Sigma, Science Park Road, Singapore, Singapore) yang dilarutkan dalam larutan carboxymethylcellulosa (CMC) 1\% (Sigma, St Louis, MA, USA). Obat diberikan secara oral 1 kali sehari selama 14 hari. Prosedur operasi diawali dengan melakukan anastesi kombinasi $90 \mathrm{mg} / \mathrm{kg}$ BW ketamine and $10 \mathrm{mg} / \mathrm{kb} \mathrm{BW}$ xylazine secara intra peritoneal. ${ }^{23}$

\section{Pemeriksaan histologi hepar}

Blok paraffin dipotong dengan ketebalan $4 \mu \mathrm{m}$ dan dilakukan pengecatan menggunakan perwarnaan hematoxylin eosin (HE). Analisis histopalotogi jaringan hepar dinilai untuk mengetahui gambaran degenerasi hidropis dan nekrosis. Penilaian secara semikuantitatif terhadap degenerasi hidropis berdasarkan: penonjolan pada membran plasma, penambahan jumlah eosinofil, sel tampak membesar atau bengkak, sitoplasma tampak pucat dan inti tetap berada ditengah. Sedangkan penilaian secara semikuantitatif terhadap nekrosis hepar berdasarkan: warna basofil inti sel akan memudar hingga menghilang (kariolisis), inti sel yang mengecil dan warna basofil meningkat (piknosis), inti yang mengalami fragmentasi (karioreksis), inti sel tidak berada didalam membran plasma) dan rusaknya membran plasma. Nilal 0 (normal) apabila terjadi perubahan $<25 \%$, nilai 1 (ringan) bila terjadi perubahan $25-50 \%$, nilai 2 (sedang) bila terjadi perubahan 50$75 \%$, dan nilai 3 (berat) bila terjadi perubahan $>75 \%$. Analisis dilakukan secara blinding dalam lima lapangan pandang menggunakan mikroskop cahaya yang terhubung dengan komputer (optilab) pada pembesaran 400x (Gambar 1). ${ }^{24}$

\section{Analisis statistik}

Analisis statistik menggunakan software IBM SPSS Statistics versi 23. Uji normalitas 
data menggunakan Shapiro-wilk test. Data dalam bentuk mean \pm SD, dengan nilai dianalisis menggunakan uji One-Way Anova bermakna p<0,05.

dan post hoc LSD. Hasil penelitian disajikan

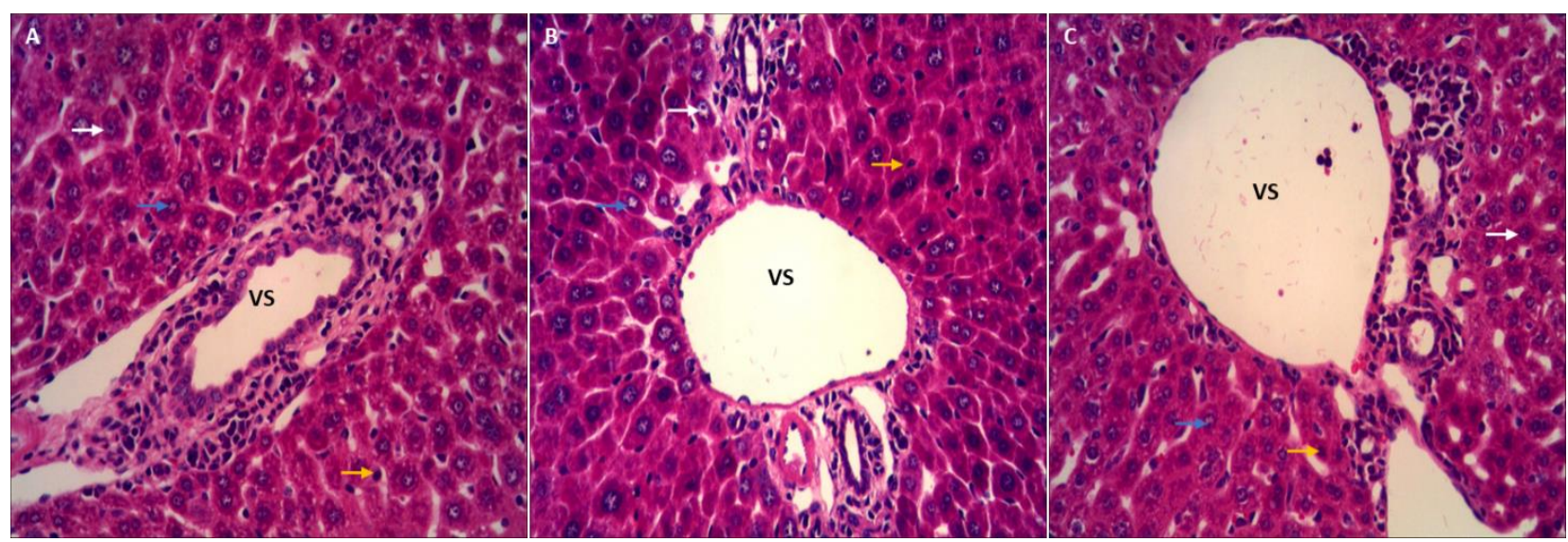

Gambar 1. Gambaran mikroskopik hepar dengan pewarnaan HE. Sel hepar normal (tanda panah putih), degenerasi hidropis (tanda panah biru), nekrosis (tanda panah kuning). Pembesaran 400x. (A) SN (nefrektomi 5/6 subtotal); (B) S5 (nefrektomi 5/6 subtotal + simvastatin 5,2 $\mathrm{mg} / \mathrm{kgBB}$ ); (C) $\mathrm{S} 10$ (nefrektomi 5/6 subtotal + simvastatin 10,4 mg/kgBB); (VS) Vena Sentralis.

\section{HASIL}

\section{Degenerasi hidropis hepar}

Berdasarkan hasil pemeriksaan histopatologi diperoleh data bahwa rerata degenerasi hidropis pada kelompok SN $(1,24 \pm 0,19)$, kelompok S5 $(0,64 \pm 0,11)$, dan kelompok S10 $(0,92 \pm 0,41)$. Hasil uji Oneway Anova memperoleh nilai $\mathrm{p}<0,05$. Hasil ini menunjukkan bahwa terdapat perbedaan signifikan gambaran histopatologi hepar pada model subtotal nefrektomi dengan pemberian statin. Hasil uji LSD (Gambar 2) menunjukkan bahwa terdapat perbedaan signifikan pada penilaian degenersi hidropis pada kelompok SN dan kelompok S5 $(\mathrm{p}<0,05)$. Akan tetapi, tidak terdapat perbedaan signifikan pada gambaran histopatologi degenerasi hidropis hepar pada kelompok SN dengan kelompok S10 ( $p>0,05)$. Disamping itu, tidak terdapat perbedaan signifikan pula antara kedua peringkat dosis simvastatin (S5 dan $\mathrm{S} 10)(\mathrm{p}>0,05)$.

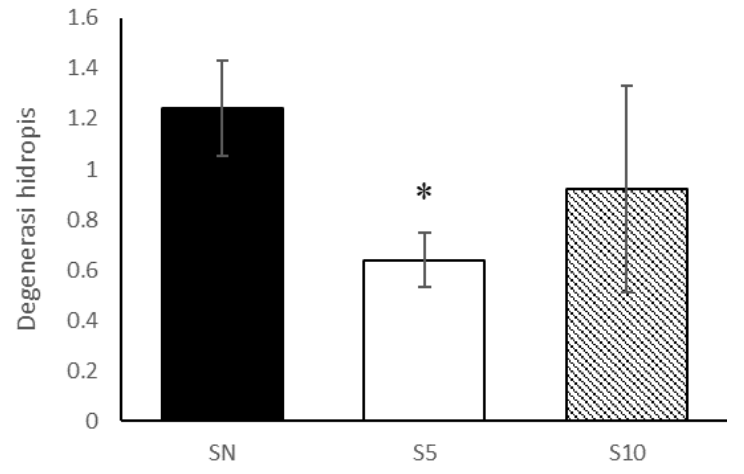

Gambar 2. Analisis Degenerasi Hidropis Hepar. Uji One-way Anova dan post-hoc LSD. ${ }^{*} \mathrm{p}<0,05$ vs SN. SN (nefrektomi 5/6 subtotal), S5 (nefrektomi 5/6 subtotal + simvastatin 5,2 $\mathrm{mg} / \mathrm{kgBB}$ ), S10 (nefrektomi 5/6 subtotal + simvastatin $10,4 \mathrm{mg} / \mathrm{kgBB}$ ).

\section{Nekrosis hepar}

Berdasarkan hasil analisis histopatologi diperoleh data bahwa nekrosis sel pada kelompok SN $(1,46 \pm 0,29)$, kelompok S5 $(0,96 \pm 0,27)$, dan kelompok S10 $(0,74 \pm 0,21)$. Hasil uji One-way Anova memperoleh nilai $(\mathrm{p}<0,05)$. Hasil ini menunjukkan bahwa terdapat perbedaan signifikan pada gambaran histopatologi hepar pada model subtotal nefrektomi dengan pemberian statin. Hasil uji post-hoc LSD (Gambar 3) menunjukkan 
bahwa terdapat perbedaan signifikan antara kelompok hewan yang memperoleh simvastatin (S5 dan S10) dengan kelompok SN $(p<0,05)$. Akan tetapi, tidak terdapat perbedaan signifikan pada peringkat dosis simvastatin.

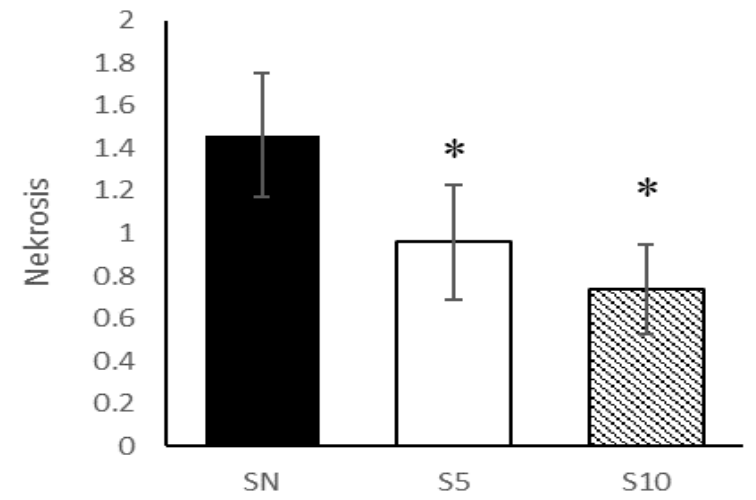

Gambar 3. Analisis Nekrosis Hepar. Uji One-way Anova dan post-hoc $L S D$. ${ }^{*} \mathrm{p}<0,05$ vs SN. SN (nefrektomi 5/6 subtotal), S5 (nefrektomi 5/6 subtotal + simvastatin $5,2 \mathrm{mg} / \mathrm{kgBB}), \quad \mathrm{S} 10$ (nefrektomi $5 / 6$ subtotal + simvastatin 10,4 $\mathrm{mg} / \mathrm{kgBB})$.

\section{DISKUSI}

\section{Degenerasi hidropis}

Degenerasi hidropis merupakan jejas reversibel yang terjadi akibat kegagalan pompa natrium-kalium ATPase pada membran plasma. Kondisi ini mengakibatkan sel tidak mampu mempertahankan homeostasis ion dan cairan. Berkurangnya aktivitas ATP membran plasma menyebabkan tertimbunnya sodium di dalam sel dan keluarnya kalium dari dalam sel. Akibatnya, terjadi penambahan air sehingga sel mengalami pembengkakkan. Ketika pembengkakkan sel berlangsung vakuola dapat terbentuk di sitoplasma dan retikulum endoplasma mengalami dilatasi. Akan tetapi, jejas ini dapat dikoreksi dan sel akan menjadi normal kembali. Agen fisis, kimia, faktor genetik dan faktor lingkungan dapat menjadi pemicu timbulnya jejas ini. ${ }^{7,25}$

Degenerasi hidropis hepar pada kondisi gagal ginjal kronis mungkin disebabkan karena stres kronik yang dapat meningkatkan kadar ROS, sehingga menginduksi saraf simpatis dan terjadi pengaktifan hormon glukokortikoid. Pada kondisi normal hepar dan ginjal berperan sebagai penghasil antioksidan di dalam tubuh serta menetralisir radikal bebas. Namun, gangguan pada hepar dan kerusakan pada sel tubular ginjal, dapat memicu peningkatan radikal bebas yang dapat merubah sel normal. ${ }^{26,27}$

Pada penelitian ini, degenerasi hidropis pada kelompok yang memperoleh simvastatin (S5 dan S10) lebih rendah dibandingkan dari SN. Hal ini kemungkinan disebabkan karena, simvastatin disamping sebagai antidislipidemia juga memiliki efek antiinflamasi dan antioksidan. ${ }^{28}$ Statin selama ini digunakan untuk mengurangi kadar kolesterol, namun dalam beberapa tahun terakhir statin menarik lebih banyak perhatian karena memiliki efek lain, yaitu efek antioksidan, antiinflamasi, dan antiiskemik.. ${ }^{14-}$ ${ }^{16}$ Efek antioksidan statin kemungkinan terjadi melalui mekanisme lipid-lowering-dependent dan lipid-lowering-independent. ${ }^{17}$

\section{Nekrosis}

Nekrosis merupakan jejas irreversibel yang dapat terjadi akibat adanya paparan zat dari luar maupun dari dalam tubuh, sehingga memicu terjadinya kematian sel maupun jaringan. Jejas sel dapat terjadi akibat kelainan fungsional dan biokimia pada satu atau beberapa komponen fungsional dari sel. Nekrosis dapat terjadi akibat stimulus seperti agen infeksi (bakteri, virus, jamur, parasit), hipoksia, dan kondisi lingkungan yang ekstrim. Nekrosis ditandai dengan pembengkakkan sel dan organel sitoplasma (terutama mitokondria), diikuti oleh pecahnya membran plasma. Mitokondria yang tidak adekuat menghasilkan ATP akibat kondisi hipoksia, menjadi salah satu penyebab terjadinya nekrosis. ${ }^{7,29}$ 
Pada penelitian ini ditemukan bahwa pada kondisi gagal ginjal kronik terjadi nekrosis pada sel-sel hepatosit. Hal ini dimungkinakan karena terdapat kaitan antara hepar dan ginjal yang sangat erat dalam fungsi mengekresikan zat sisa yang sudah tidak diperlukan dalam tubuh. Pada gagal ginjal kronik kadar BUN dan creatinine serum akan meningkat. Urea yang bersifat toksik yang ada di dalam tubuh akan didetoksifikasi oleh organ hepar dan apabila terakumulasi sangat banyak didalam tubuh akan dapat merusak hepatosit. Walaupun demikian, indikator terbaik dalam mengukur terjadi kerusakan pada hepar keseluruhan adalah level serum bilirubin., Nekrosis terjadi terutama di sekitar vena sentralis dan periportal zone. Kondisi ini terjadi akibat faktor iskemia maupun obatobatan. ${ }^{30}$

Penelitian ini juga ditemukan bahwa simvastatin secara signifikan memperbaiki nekrosis pada sel hepatosit. Hal ini kemungkinan karena statin memiliki efek protektif, antiproliferatif, dan apoptosis. ${ }^{31}$ Statin juga dilaporkan dapat menginduksi kruppel-like factor 2 (KLF2) sebagai faktor penghambat hepatic stellate cells (HSC) yang memicu sirosis hati, serta dapat memperbaiki sel endotel hati yang disfungsional. ${ }^{32}$ Penggunaan statin yang menyebabkan toksitas terhadap hepatosit juga masih langka, hanya sekitar 3\% terkecuali penggunaan dosis tinggi serta penggunaan jangka panjang. ${ }^{33}$ Statin juga dilaporkan memiliki efek antioksidan, yang mampu memperbaiki sel. Rosuvastatin dosis 20mg/hari, dilaporkan mampu menurunkan kadar oxidative-stress dan menurunkan kadar LDL (low-density lipoprotein) pada tubuh. ${ }^{17}$

\section{SIMPULAN}

Simvastatin memperbaiki degerasi hidropis dan nekrosis sel hepatosit mencit subtotal nefrektomi

\section{UCAPAN TERIMA KASIH}

Terima kasih kami ucapkan kepada Fakultas Kedokteran dan Ilmu Kesehatan Universitas Warmadewa atas dukungan yang diberikan pada penelitian ini.

\section{PERNYATAAN}

Tidak terdapat konflik kepentingan pada penelitian ini.

\section{DAFTAR PUSTAKA}

1. GDB Chronic Kidney Disease Collaboration. Global, regional, and national burden of chronic kidney disease, 1990-2017; a systematic analysis for the global burden of disease study 2017. Lancet. 2020;395:709-33.

2. Taufikuromah T, Sanjaya IGM, Baktir A, dkk. Perubahan Histokimia Hati dan Ginjal Mencit Terpapar Merkuri serta Pemulihannya dengan Nanogold. Molekul. 2016;11:80-91.

3. Hall JE. Guyton dan Hall Buku Ajar Fisiologi Kedokteran, Edisi ke-12. Singapura: Elsevier; 2014. p.877-886.

4. Targher G, Bertolini L, Rodella S, dkk. Relationship between kidney function and liver histology in subjects with nonalcoholic steatohepatitis. Clin J Am Soc Nephrol. 2010;5:2166-71.

5. Suwitra K. Penyakit Ginjal Kronik. Dalam: Setiati S, Alwi I, Sudoyo AW, editor. Ilmu Penyakit Dalam. Edisi ke-6. Jakarta: Interna Publishing; 2014. p.21617.

6. Silvertorn DU. Fisiologi Manusia: Sebuah Pendekatan Terintegrasi, Edisi ke-6. Jakarta: EGC; 2013. p.772-83.

7. Kumar V, Abbas AK, Aster JC. Buku Ajar Patologi Robbins, Edisi ke-9. Singapura: Elsevier Inc; 2015.

8. Bayupurnama P. Hepatototoksisitas imbas obat. Dalam: Setiati S, Alwi I, Sudoyo 
AW, editor. Ilmu Penyakit Dalam. Edisi ke-6. Jakarta Pusat: Interna Publishing; 2014. p.2009-14.

9. Thapar M, Russo MW, Bonkovsky HL. Statins and Liver Injury. Gastroenterol Hepatol (N Y). 2013;9;605-6.

10. Karahalil B, Hare E, Koç G, Uslu I, Sentürk K, Özkan Y. Hepatotoxicity Associated with Statins. Arh Hig Rada Toksikol. 2017;68:254-60.

11. Russo MW, Hoofnagle JY, Gu J, dkk. Spectrum of Statin Hepatotoxicity: Experience of the Drug-Induced Liver Injury Network. Hepatology. 2014;60:679-86.

12. Eghbal MA, Abdoli N, Azarmi Y. Efficiency of Hepatocyte Pretreatment with Coenzyme $\mathrm{Q}_{10}$ Againts Statin Toxicity. Arh Hig Rada Toksikol. 2014;65:101-8.

13. Abdoli N, Heidari R, Azarmi Y, dkk. Mechanism of the Statins Cytotoxicity in Freshly Isolated Rat Hepatocytes. J Biochem Mol Toxicol. 2013;27:287-94.

14. Mohammadi MT, Amini R, Jahanbakhsh Z, dkk. Effects of Atorvastatin on the Hypertension-Induced Oxidative Stress in the Rat Brain. Iran Biomed J. 2013;17:152-7.

15. Davaro F, Forde SD, Garfield M, dkk. 3Hydroxyl-3-methylglutaryl Coenzyme A (HMG-CoA) Reductase Inhibitor (Statin)induced28-kDa Interleukin-1 $\beta$ interferes with Mature IL-1 $\beta$ Signaling. J Biol Chem. 2014;289:16214-22.

16. Malfitano AM, Marasco G, Proto MC, dkk. Statins in Neurological Disorders: An Overview and Update. Pharmacol Res. 2014;88:78:74-83.

17. Moon GJ, Kim SJ, Cho YH, dkk. Antioxidant Effects of Statins in Patients with Atherosclerotic Cerebrovascular Disease. J Clin Neurol. 2014;10:140-7.
18. Mikolasevic I, Zutelija M, Mavrinac V, dkk. Dylipidemia in Patients with Chronic Kidney Disease: Etiology and Management. Int J Nephrol Renovasc Dis. 2017;10:35-45.

19. Kanbay M, Turgut F, Covic A, dkk. Statin Treatment for Dyslipidemia in Chronic disease and Renal Transplantation: A review of the Evidence. $J$ Nephrol. 2009;22:598-609.

20. Cahyawati PN, Ngatidjan, Sari DCR, dkk. Simvastin Attenuates Renal Failure in Mice with a 5/6 Subtotal Nephrectomy. Int J Pharm Pharm Sci. 2017;9:12-7.

21. Cahyawati PN, Lestari DPO, Siskayani AS, dkk. Simvastatin Improves Renal Function and Glomerulosclerosis in Ischemic-reperfusion Injury. Indones Biomed J. 2020;12:143-8.

22. Cahyawati PN, Arfian N, Ngatidjan N. Effect of statin on vascular wall thickness in kidney disease model. IOP Conf. Ser.: Mater. Sci. Eng. 2018;434:012324.

23. Cahyawati PN. Effect of Simvastatin on Histopathology of The Heart After 5/6 Subtotal Nephrectomy. International Journal of Applied Pharmaceutics. 2019;11:131-3.

24. Fitmawati, Titrawani, Safitri W. Struktur Histologi Hati Tikus Putih (Rattus norvegicus Berkenhout 1769) dengan Pemberian Ramuan Tradisional Masyarakat Melayu Lingga, Kepulauan Riau. Ekotonia: Jurnal Penelitian Biologi, Botani, Zoologi dan Mikrobiologi. 2018;03:11-9.

25. Wallig MA, Janovitz EB. Morphologic Manifestations of Toxic Cell Injury. Dalam: Haschek WM, Rousseaux CG, Wallig MA, editor. Haschek and Rousseaux's Handbook of Toxicologic Pathology. Edisi ke-3. USA: Academic Press; 2013. p.77-105. 
26. Miryam VM, Alejandro HS, Luis FUV. 30. Krishna M. Patterns of Necrosis in Liver Plasma Cortisol Activity in Rats Under Conditions of Chronic Stress Disease. Clin Liver Dis (Hoboken). Supplemented with Resveratrol. Colombia Medica. 2012;43:221-5.

27. Amiri M. Oxidative Stress and Free Radicals in Liver and Kidney Diseases; an Updated Short-review. J Nephropathol. 2018;7:127-31.

2017;10:53-6.

31. Mansourian PG, Yoneda M, Rao K, dkk. Effects of Statins on the Risk of Hepatocellular Carcinoma. Gastroenterol Hepatol (N Y). 2014;10:417-26.

32. Marrone G, Maeso-Diaz R, GarciaCardena G, dkk. KLF2 Exert Antifibrotic

28. Criner GJ, Connett JE, Aaron SD, dkk. and Vasoprotective Effects in Cirrhotic Simvastatin for the Prevention of Exacerbations in Moderate-to-Severe COPD. N Engl J Med. 2014;370:2201-10.

29. Adigun R, Bhimju SS. Cell (Liquefactive Coagulative, Caseous, Fat, Fibrinoid, and Gangrenous). Treasure Island: Stat Pearls Publishing; 2018. Rat Livers: Behind the Molecualar Mechanisms of Statins. Gut. 2015;64:1434-43.

33. Moon GJ, Kim SJ, Cho YH, dkk. Antioxidant Effects of Statins in Patients with Atherosclerotic Cerebrovascular Disease. J Clin Neurol. 2014;10:140-7. 